Please do not remove this page

RMIT

UNIVERSITY

\title{
Analysis of disruptions caused by construction field rework on productivity in residential projects
}

Arashpour, Mehrdad; Wakefield, Ronald; Blismas, Nick; Lee, Eric

https://researchrepository.rmit.edu.au/esploro/outputs/9921859198301341/filesAndLinks?institution=61RMIT_INST\&index=null

Arashpour, M., Wakefield, R., Blismas, N., \& Lee, E. (2014). Analysis of disruptions caused by construction field rework on productivity in residential projects. Journal of Construction Engineering and Management, 140(2), 1-12. https://doi.org/10.1061/(ASCE)CO.1943-7862.0000804

Document Version: Accepted Manuscript

Published Version: https://doi.org/10.1061/(ASCE)CO.1943-7862.0000804

Repository homepage: https://researchrepository.rmit.edu.au

(C) 2013 American Society of Civil Engineers.

Downloaded On 2023/04/26 23:19:48 +1000 
Thank you for downloading this document from the RMIT Research Repository.

The RMIT Research Repository is an open access database showcasing the research outputs of RMIT University researchers.

RMIT Research Repository: http://researchbank.rmit.edu.au/

\section{Citation:}

Arashpour, M, Wakefield, R, Blismas, N and Lee, E 2013, 'Analysis of disruptions caused by construction field rework on productivity in residential projects', Journal of Construction Engineering and Management, pp. 1-12.

See this record in the RMIT Research Repository at:

http://researchbank.rmit.edu.au/view/rmit:22586

Version: Accepted Manuscript

Copyright Statement: (c) 2013 American Society of Civil Engineers

Link to Published Version:

http://dx.doi.org/10.1061/(ASCE)C0.1943-7862.0000804 
The published version of this paper is available in the ASCE Civil Engineering Database: http://cedb.asce.org/

\section{Analysis of disruptions caused by construction field rework on productivity in residential projects}

\section{Mehrdad Arashpour, S.M.ASCE ${ }^{1}$; Ron Wakefield, M.ASCE ${ }^{2}$; Nick Blismas ${ }^{3}$; EWM Lee $^{4}$}

Abstract: Operational performance in residential construction production systems is assessed based on measures such as average house completion time, number of houses under construction, lead time and customer service. These systems, however, are prone to nonuniformity and interruptions caused by a wide range of variables such as inclement weather conditions, accidents at work sites, fluctuations in demand for houses and rework. The availability and capacity of resources therefore are not the sole measures for evaluating construction production systems capacity especially when rework is involved. The aim of this paper is to investigate the effects of rework time frame and frequency/length on tangible performance measures. Furthermore, different call-back time frames for rework and their impact on house completion time are modeled and analyzed. Volume home building was chosen as the industry sector studied in this investigation because it is a data-rich environment. We designed several experiments to model on time, late and early call-back time frames in presence of rework with different length and frequency. Both mathematical modeling and discrete event simulation were then used to compare and contrast outputs. The measurements showed that the average completion time is shorter in systems interrupted by frequent but short rework. That is, a smaller downstream buffer between processes is required to avoid work starvation than those systems affected by infrequent but long interruptions. Furthermore, early call-backs for rework can significantly increase the number of house completions over the long run. This indicates that there is an opportunity for the mass house building sector to improve work practice and project delivery by effectively managing rework and its related variables. This research builds on the current body of knowledge by applying even flow production theory to the analysis of rework in the residential 
construction sector, with the intention of ensuring minimal disruption to the construction production process and improving productivity.

CE Database subject headings: Computer aided simulation; Construction management; Mathematical models; residential; Production management; Inspection; Project management; Quantitative analysis

Author Keywords- Computer simulation; Call-back timeframe; Interruption; Mathematical modelling; Production planning; Productivity; Queue depletion rate; Rework frequency and duration; Volume house building; Work flow variability

${ }^{1}$ Ph.D. Candidate, School of Property, Construction and Project Management, RMIT Univ., Melbourne, VIC, Australia; E-mail: mehrdad.arashpour@rmit.edu.au

${ }^{2}$ Professor of Construction, Head of School of Property, Construction and Project Management, RMIT Univ., Melbourne, VIC, Australia; E-mail: ron.wakefield@rmit.edu.au

${ }^{3}$ Associate Professor, School of Property, Construction and Project Management, RMIT Univ., Melbourne, VIC, Australia; E-mail: nick.blismas@rmit.edu.au 
${ }^{4}$ Assisstant Professor, Department of Civil and Architectural Engineering, City Univ. of Hong Kong, Kowloon, Hong Kong, China; E-mail: ericlee@cityu.edu.hk

\section{Introduction}

Production cycle time is usually regarded as one of the main performance measures in projects (Hopp and Spearman 2008). Attempts have been made to optimize both pre-construction and construction phases in order to shorten completion times. While improvements in both pre-construction and construction phases have been considerable, the construction industry is still regarded as fragmented, with much room for improvement (Ballard and Koskela 2009).

Traditional project planning uses Critical Path Method (CPM) as its main tool. However, there is a degree of skepticism about the capability of CPM to manage interconnected construction processes (Tommelein, Riley et al. 1999). In fact, traditional project management tools such as CPM scheduling, earned value analysis and cost estimating fall short when representing interlinked processes and the frequent seize and release of required resources that happens in residential building practice (Bashford, Walsh et al. 2003).

To address these issues, a production planning worldview in construction, which is inspired by manufacturing, focuses on not only individual activities but also interlinked resources. This school of thought in construction management has emerged based on the theory of hierarchical construction operations (Halpin and Woodhead 1976). Production management uses Discrete Event Simulation (DES) for modeling and scheduling. The historical development of construction simulation languages is presented in the background section of this paper. Over the past decade attempts have been made to develop and test construction production theories in addition to tools (Koskela 2000, Bashford, Walsh et al. 2003, Salem, Solomon et al. 2006).

Although DES modeling can illustrate interruptions in workflow, improvements are required to distinguish the unique characteristics of interruptions in construction (Akhavian and Behzadan 2011). In the process of construction, rework can interrupt workflow in different ways. Faults in the work of trade contractors are inspected internally by the builder's supervisors or externally by building 
surveyors or another third party. The responsible trade contractor is then called back to rectify the fault. In an ideal situation rework is executed between other construction processes (Arashpour, Shabanikia et al. 2012). However, it often becomes priority work that should be undertaken immediately (Sawhney, Walsh et al. 2009). Furthermore, length and frequency of rework can affect production performance significantly. Modeling the detailed process of rework in construction, which is analogous to "re-entrant flow" in production systems, has been regarded as difficult in the literature and requiring more research and investigation (Damrianant and Wakefield 2000, Brodetskaia, Sacks et al. 2013).

To bridge this gap, this study uses an innovative approach tailored to the construction context, in order to model and analyze interruptions of different kinds. Twelve experiments have been designed by varying: (1) the length of interruptions caused by rework; (2) frequency of rework; (3) the timeframe of call-backs for rework. Both analytical and simulation modeling have been used to robustly compare and contrast performance measures in presence of these variables. The investigation has been conducted in production homebuilding sector because mass homebuilders usually record production data systematically. Although this sector provides the scope for current study, results are generalizable to other parts of the construction industry. 


\section{Background}

In this section, previous works that have focused on causes and modeling construction rework are reviewed.

\section{Causes of construction rework}

There are many discussions of rework in the construction literature. Contributors to rework can be classified into some main categories: construction planning and scheduling, engineering and reviews, human resource capability, material and equipment supply, and leadership and communication (Fayek, Dissanayake et al. 2004). Under such classification, root causes of construction field rework involve but are not limited to: constructability problems (Feng 2009), unrealistic schedules (Love, Edwards et al. 2010), changes in project scope (Tuholski 2008), poor document control (Love, Edwards et al. 2009), unclear instruction to workers (Thompson and Perry 1992), insufficient skill levels (Mubarak 2010), lack of safety (Garza, Hancher et al. 2000, Rajendran, Gambatese et al. 2009), ineffective project management team (Love, Holt et al. 2002, Choi, Kwak et al. 2011), untimely supply of materials (O'Brien, Wang et al. 2006, Hwang, Park et al. 2012), and non-compliance with specifications (Sawhney, Bashford et al. 2005).

Furthermore, concurrency in the project execution is another contributor to rework. As short time-tomarket is becoming more important in today's construction industry, processes are started before their predecessors are completely finished. Although the so called management strategy of fast tracking can help meeting the scheduled time-to-market and therefore greater market share, it can add hidden costs such as rework costs to projects (Salazar-Kish 2001, Touran 2010). Project management tools such as Critical Path Method (CPM) do not capture these and decisions on rework are made based on managers' judgment. Therefore finding new approaches to model rework and quantitatively measuring its effect on production parameters are of the great importance. Discrete event simulation (DES) is a useful tool for research purposes in the field of construction processes and rework (Martinez 2010). 


\section{Modeling of rework}

There are many variables in a construction project that make the models very complex. Simulation modeling is a useful tool to analyze those construction models that cannot be solved analytically. Simulation is capable of providing information about system behavior under different what-if conditions (AbouRizk, Halpin et al. 2011). Construction simulation tools have been widely developed and used in order to model production processes. Fig. 1 shows the evolutionary trend of both general purpose and domain-specific tools in construction simulation.

General purpose construction simulation too Special purpose construction simulation tool

\section{SIMPHONY (Hajjar 1999) \\ CRUISER (AbouRizk and Hajjar 1998) \\ AP2-Earth (Hajjar and AbouRizk 1997)} STROBOSCOPE (Martínez 1996)

DISCO (Huang and Halpin 1995)

SEACONS (McCahill and $\quad$ HKCONSIM (Lu, Anson et INSIGHT (Paulson Jr, Chan et al. 1987)

RESQUE (Chang 1986) Bernold 1993) al. 2003)

SCRAPESIM (Clemmens and Willenbrock 1978)

CYCLONE (Halpin 1973)

$$
\underline{1970 \text { s }}
$$

SIREN (Kavanagh 1985)

MicroCYCLONE (Lluch and Halpin 1982)
COSYE (AbouRizk and Hague 2009)

WebCYCLONE (Jen 2005)

Fig.1. Historical evolution of construction simulation tools

These construction simulation languages have been used to model construction processes and relative parameters such as completion time and work-in-process inventory (Naresh and Jahren 1995, Kamat and Martinez 2008, González, Alarcón et al. 2009, Behzadan and Kamat 2011). However, the literature is sparse concerning models for construction management systems that involve consideration of rework caused by design information changes and quality problems. To mention some examples, Brodetskaia, Sacks et al. (2013) analyzed "reentrant workflow patterns" in high-rise residential construction. Also some researchers have focused on modeling quality inspections and 
their impact on production parameters. For instance, Sawhney, Walsh et al. (2009) used a composite modeling element in SIMPHONY to investigate the impact of inspections pass rate on production output.

Another stream of research adopted mathematical and graphical modeling tools such as Petri Nets (PNs) in order to enhance modeling of construction processes. Petri Nets methodology (Petri 1966) facilitates a realistic modeling of delays in the process of construction. For example, Wakefield and Sears (1997) and Sawhney, Abudayyeh et al. (1999) used Petri Nets for simulation and modeling of construction systems. However, only a few studies have investigated the interferences in construction processes using mathematical modeling. Damrianant and Wakefield (2000) and Lu and Ni (2008) used time and color Petri nets to model interruptions in discrete-event systems. In the limited available studies, over-simplistic assumptions such as deterministic process times and interruption durations have made the models too distant from the reality of construction sites.

Modeling interruptions between and during processes has been regarded as difficult in the literature, requiring more research and investigation (Damrianant and Wakefield 2000, Boukamp and Akinci 2007). The present paper aims to bridge this gap.

\section{Modeling of production homebuilding processes}

Construction processes are usually modeled in an interdependent network of predecessors and successors. In this study volume homebuilding sector was selected as the scope because it is a datarich environment.

In the common scenario in Australia, mass homebuilders subcontract up to 100 homebuilding processes to about 50 specialized trade contractors (Dalton, Wakefield et al. 2011). The common production strategy is make-to-order and there is no building on speculation. Builders' superintendents or construction supervisors are responsible for managing movement of work (handoffs) among trade contractors. Upon completion of a process, trade contractors release their resources and engage them again in the next job. There are two main requirements for starting a 
process at its scheduled time: timely completion of preceding processes, and delivering high quality work without need to call-back for rework. As an example, roofing contractor is dependent on the timely and quality work of framing trade contractor as their predecessor and a call-back is required upon existence of faults in roof trusses.

Construction processes are resource constrained and can only be executed upon the availability of resources such as labor, material and information. As an example, the process of concreting the foundation slab as part of the production homebuilding network is illustrated in Fig. 2.

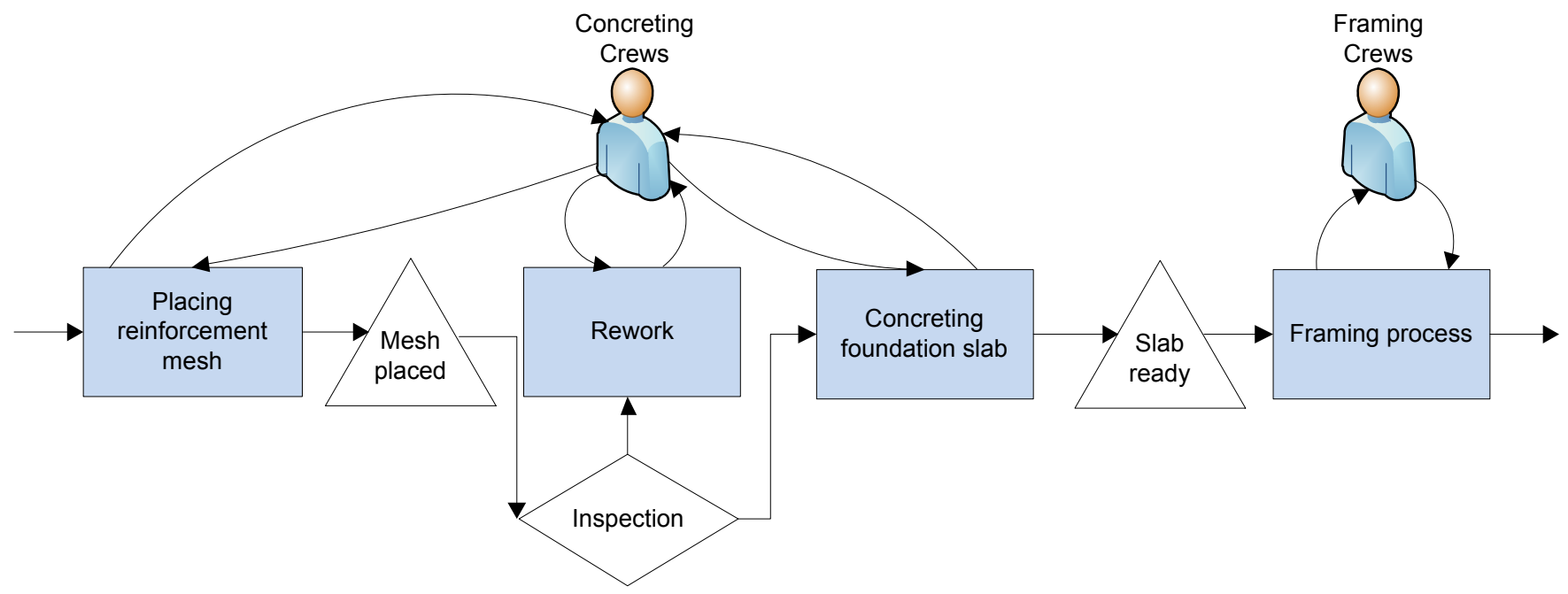

Fig.2. Process of concreting foundation slab as a part of production homebuilding

The complete model of production homebuilding including 50 trade contractors that are responsible for about 100 processes was developed using the same method as $\mathrm{Yu}$ (2011). The focus of the model, which is illustrated in the appendix, is on labor and work flows.

\section{Modeling of interruptions caused by rework}

In practice frequency and duration of rework can affect home completion times among other production parameters (Sawhney, Walsh et al. 2009). Furthermore, the timeframe in which rework call-backs occur changes the interruption length and effect. Three possible timeframes for call-backs (rework orders) are discussed in the following section: 


\section{On time call-backs for rework before releasing resources}

The rework is usually ordered when a given construction process has been completed. In Australia, building surveyors carry out four external inspections on major building stages - foundation, framing, lock-up/waterproofing, and pre-occupancy. In addition, within-organization inspections are conducted by builders to identify any fault. In the event of a fault, responsible trade contractor is called back to rectify it. After the necessary rework has been done, the following trade contractor can then initiate their process. Fig. 3 presents the timescale for foundation rework before the resources have been released.

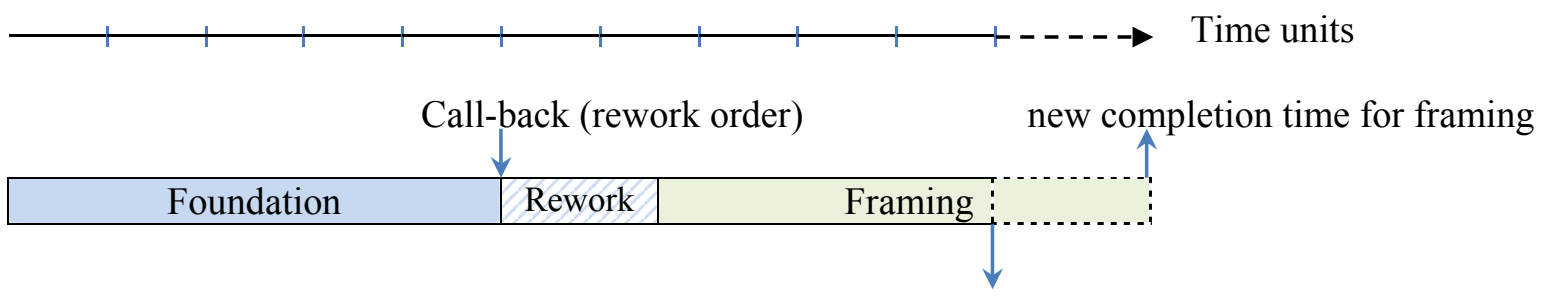

Scheduled completion time for framing

Fig.3. Timescale for call-back and rework before releasing resources

Since the on time call-back triggers the rework right at the completion time of the process, a later completion time is expected.

\section{Late call-backs for rework after releasing resources}

Faults are sometimes discovered after initiation of the construction processes that follow. In such a situation, call-backs for rework are made after the responsible trade contractor has left the site and resources have been released. In this case, rework becomes priority work for the responsible trade contractor (Sawhney, Walsh et al. 2009). This is unique to construction industry - in manufacturing for example, rework is commonly regarded as a non-preemptive failure, which can be performed between processes (Hopp, Iravani et al. 2011). Fig. 4 illustrates the timescale for foundation rework after foundation process resources have been released. 


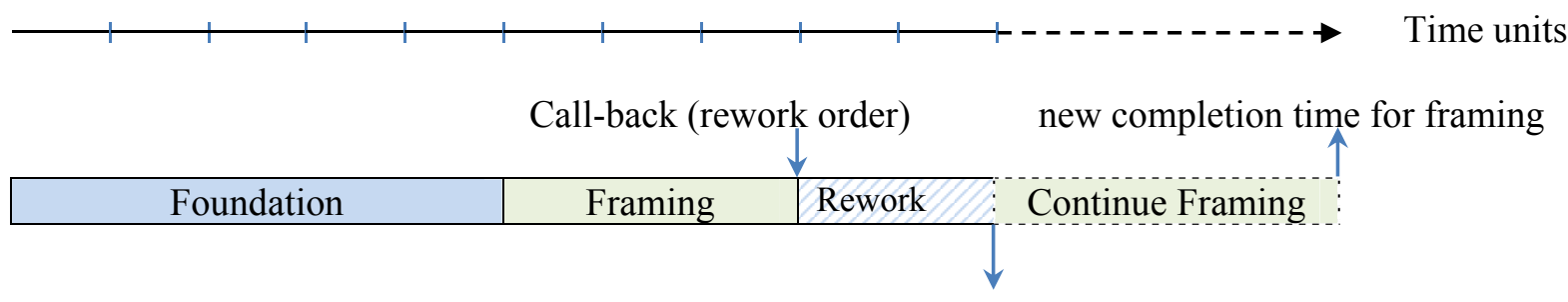

Scheduled completion time for framing

Fig.4. Timescale for call-back and rework after releasing resources

In Fig. 4, the late call-back for rework causes the framing process to be broken into separate parts and therefore has the potential to create long delays. Here, it is assumed that the framing crew will be available when called back after completion of the foundation rework. In most cases, trade contractors are not dedicated to a single project, and will leave to do another job while their processes are interrupted. This may significantly lengthen delays.

\section{Early call-backs for rework prior to process completion- collaborated hand-offs}

Close supervision and coordination of construction can result in call-backs for rework being made during the execution of a given process. In this event, the responsible trade contractor for the rework is able to use already engaged resources to rectify the fault. Upon the availability of sufficient resources, the trade contractor may be able to complete rework using some of the crew while others move to the next job. This is only possible in building detached homes where work sites are not congested and there is easy access for two interacting contractors to work concurrently. In this way, delays can be minimized. A schematic timescale of this type of call-back and rework is shown in Fig.5.

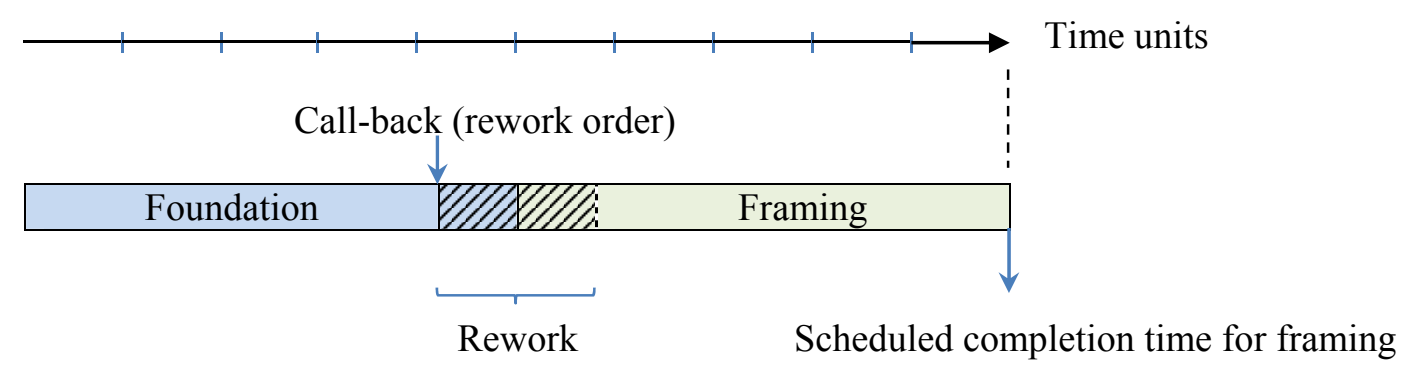

Fig. 5. Timescale of processes- call-back prior to process completion 
When there is no spatial interference, this optimal sequencing can result in timely completion of the processes.

\section{Framework for the experiments}

Previous research has analyzed rework as a significant variable in the construction workflow (Love, Holt et al. 2002). However, much of the research has focused on a few construction processes, as noted by Sawhney, Walsh et al. (2009). Therefore, this study aims to investigate the effects of callback timeframes and frequency and length of rework on performance of the whole mass homebuilding procedure. Opting for a production management approach, this investigation uses mathematical modeling and Discrete Event Simulation (DES) as the tool for a detailed modeling of volume homebuilding.

The homebuilding sector was selected as the scope for this investigation because volume homebuilders usually keep a good record of production data. The standard practice of production homebuilding in Australia is to subcontract processes to specialized trade contractors. Production data such as process times, delays, rework durations and availability of resources were collected from two mass homebuilders by numerous site observations. Then the model of homebuilding involving 50 contractors responsible for about 100 construction processes was developed using the same approach as $\mathrm{Yu}$ (2011). We conducted a total of 12 experiments to monitor the compound effect of rework variables. Frequency and length of rework along with different call-back timeframes were investigated. Both mathematical modeling of individual trade contractors and simulation modeling of the whole construction process were undertaken. The computer simulation was conducted using the ARENA simulation systems. We also utilized the SIMAN simulation coding in order to develop a more accurately tailored model of the above mentioned variables in the homebuilding context. The processes of mass homebuilding were simulated over 1000 working days to allow for the production system to move beyond its transient state. Then outputs were compared and contrasted. Care was taken to introduce as many of the existing details as possible into the experiments. 
The use of both DES simulation and mathematical models adds robustness to the present study. The results are presented and discussed in the following sections.

\section{Results and discussion}

Data obtained in previous studies showed that rework has a significant impact on construction production performance (Dalton, Wakefield et al. 2011). To analyze underlying variables of rework, we designed the experiments by varying length, frequency and call-back timeframes.

Three call-back timeframes were modeled: early, on time and late call-backs for rework. These were combined with different length and frequency of rework. As can be seen in Table 1, rework durations and intervals were assumed to be exponentially distributed in order to impose maximum randomness to experiments.

Table 1. Rework variables (frequency and length).

\begin{tabular}{lll}
\hline Rework type & $\begin{array}{l}\text { Rework Intervals } \\
\text { (days) }\end{array}$ & $\begin{array}{l}\text { Duration of Rework } \\
\text { (days) }\end{array}$ \\
\hline Very frequent-Very Short (VF-VS) & Exponential (7) & Exponential (1) \\
\hline Frequent-Short (F-S) & Exponential (14) & Exponential (2) \\
Infrequent-Long (I-L) & Exponential (21) & Exponential (3) \\
\hline Very Infrequent-Very Long (VI-VL) & Exponential (28) & Exponential (4) \\
\hline
\end{tabular}

Twelve experiments were constructed by combining three call-back time frames and four frequency and length of rework. It is worth mentioning that availability level and capacity of trade contractors undergoing all these rework classes are the same. However, tangible performance measures of the homebuilding process are expected to be different.

Observed trade contractors had different call-back frequency and timeframe. For instance, framing and roofing contractors were two most frequent called-back trades. Some other trades experienced late call-backs especially after the occupancy inspections. Understandably, these call-backs create lengthy rework as trade contractors have already moved their resources to other work sites. The histogram of rework durations is illustrated in Fig. 6. 


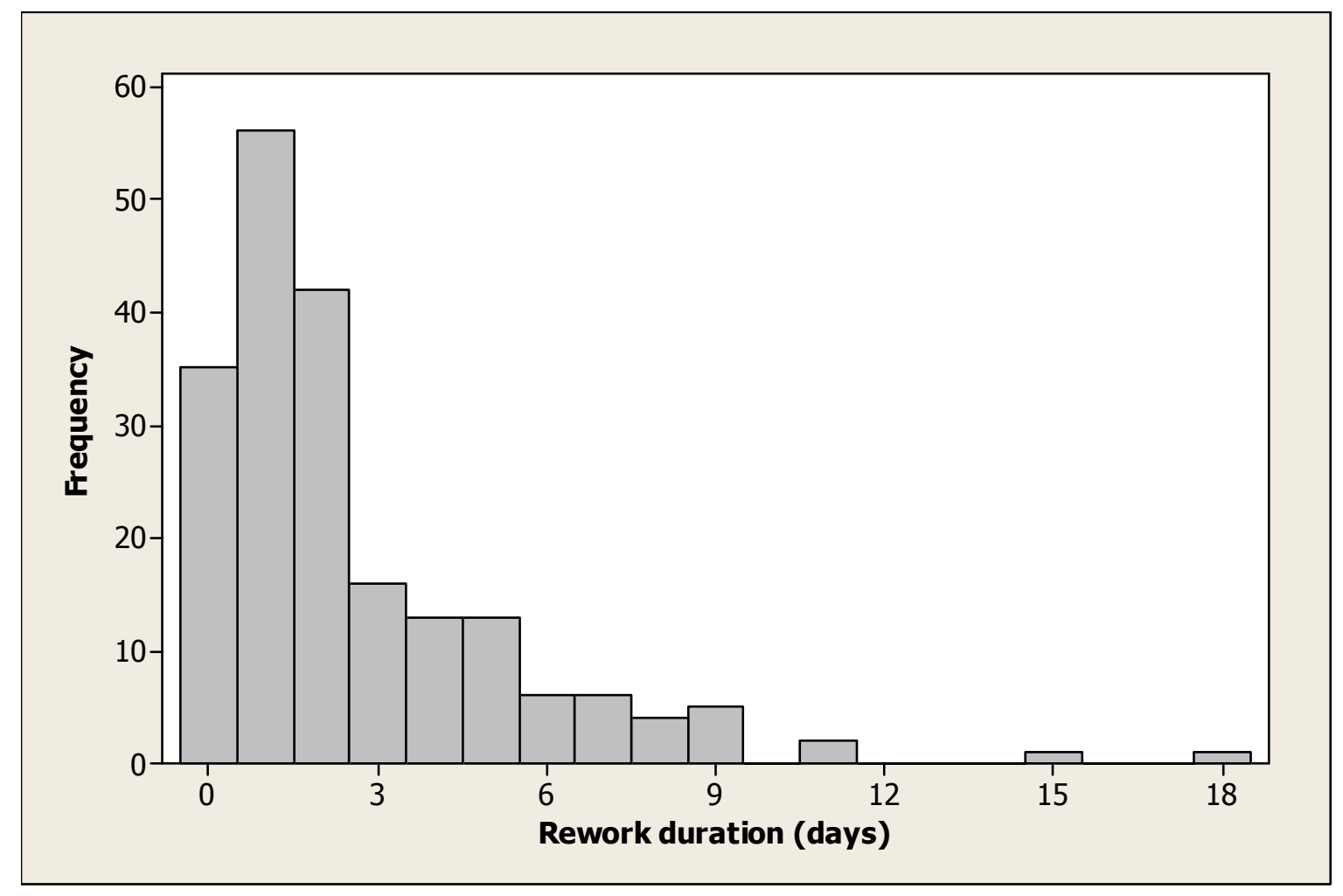

Fig. 6 Histogram of rework durations

In order to fit the best probability distribution to the rework data, ARENA Input Analyzer was used. Input analyzer automatically examines the data against all of the applicable distributions and finds the best fit based on test statistics and minimum square error values. The latter measure is the average of squares of differences between observations and the fitted probability distribution. Table 2 orders distributions from smallest to largest square error.

Table 2 Quality of fit of probability distributions to the rework data

\begin{tabular}{ccc}
\hline Order & $\begin{array}{c}\text { Probability } \\
\text { Distribution }\end{array}$ & Square error \\
\hline $\mathbf{1}$ & Exponential & 0.00275 \\
$\mathbf{2}$ & Uniform & 0.00363 \\
$\mathbf{3}$ & Triangular & 0.00436 \\
$\mathbf{4}$ & Lognormal & 0.00549 \\
$\mathbf{5}$ & Normal & 0.00666 \\
$\mathbf{6}$ & Erlang & 0.00847 \\
$\mathbf{7}$ & Beta & 0.01122 \\
$\mathbf{8}$ & Weibull & 0.06921 \\
$\mathbf{9}$ & Gamma & 0.08402 \\
\hline
\end{tabular}

As can be seen exponential distribution best fits to our empirical data based on the quality of fit measure of square error. 
In the homebuilding context, construction supervisors can play a crucial role in preventing long rework. For instance, in the process of concreting the foundation slab these items should be controlled: rebar size and quantity, overlaps, using barriers between soil and concrete, and using spacers to maintain the minimum concrete cover for the rebar. Such controls could prevent later destructive and non-destructive tests and lengthy rework. In a further step, trade contractor crews can be trained for early fault-finding in their processes and rectifying them before affecting the homebuilding production (Arashpour and Arashpour 2010). This is similar to the paradigm of Total Quality Management (TQM) in manufacturing.

\section{Mathematical modeling}

The individual construction processes of concreting the foundation slab was modelled and solved analytically. Process times of slab concreting best fitted the triangular distribution with most likely completion time of 7 days. Availability (A) of trade contractors, as the main resource in the volume homebuilding, was computed using mathematical models for production developed by Little (1961) and advanced by Hopp and Spearman (2008):

$$
\mathrm{A}=\frac{R I}{R I+D O R}
$$

In Eq. (1), RI = rework interval; DOR= duration of rework, respectively.

Rework results in delays and building up queues between processes. The common logic of processing jobs in construction queues is First-In-First-Out (FIFO) and its parameters can be computed by the following mathematical equations:

$$
\begin{aligned}
& \mathrm{t}_{\mathrm{e}}=\frac{\boldsymbol{t}}{\boldsymbol{A}} \\
& \mathrm{Q}=D O R \times T H \\
& \mathrm{QDR}=\frac{\mathbf{1}}{\boldsymbol{t}}-T H \\
& \mathrm{QDT}=\frac{\boldsymbol{Q}}{\boldsymbol{Q D \boldsymbol { R }}}
\end{aligned}
$$


In Eqs. (2) to (5), $\mathrm{t}=$ process time; $\mathrm{t}_{\mathrm{e}}=$ effective process time; $\mathrm{Q}=$ queue length after any interruption caused by rework; $\mathrm{DOR}=$ duration of rework; $\mathrm{TH}=$ throughput of a process $=1 / \mathrm{t}_{\mathrm{e}} ; \mathrm{QDR}=$ queue depletion rate; and QDT= queue depletion time, respectively.

If the next rework occurs before the queue is depleted, it adds to the queue. The pobability (P) of such conflict depends on the process time and queue depletion rate and can be computed by Eq. (6):

$$
\mathrm{P}=1-\boldsymbol{e}^{-Q D T / t}
$$

Production parameters in the process of concreting the foundation slab were analytically computed. The results for different frequency and length of rework have been presented in table 3 .

Table 3. Quantitative comparison of production parameters in presence of rework with different frequency and length

\begin{tabular}{l|llll}
\hline Parameters & VF-VS & F-S & I-L & VI-VL \\
\hline Duration of Rework & EXP (1) & EXP (2) & EXP (3) & EXP (4) \\
Availability of contractor & $87.5 \%$ & $87.5 \%$ & $87.5 \%$ & $87.5 \%$ \\
Throughput rate (TH) & 0.13 & 0.13 & 0.13 & 0.13 (job/day) \\
Queue length & 0.125 & 0.25 & 0.375 & 0.5 \\
Queue Depletion Rate & 0.018 & 0.018 & 0.018 & 0.018 \\
Queue Depletion Time & 7 & 14 & 21 & 28 (days) \\
Probability of conflict & $63 \%$ & $86 \%$ & $95 \%$ & $98 \%$ \\
$\quad$ With a future rework & & & & \\
\hline
\end{tabular}

A significant result from mathematical modeling of processes with rework reveals the effect of frequency and length of rework on tangible performance measures. Although longer intervals between rework are commonly preferable by managers, results clearly show that frequent but short weekly rework is better in terms of production parameters. The comparison of four cases in Table 3 indicates that job queues are shorter in presence of very frequent but very short (VF-VS) rework. This is in line with previous findings in production manufacturing research (Hopp and Spearman 2004). Further, it confirms findings from Tommelein, Riley et al. (1999) that construction project duration can be shortened by decreasing workflow variability inside the interlinked network of trades, where the output of predecessors is required by successors to perform their work (Parade Game). In fact, long rework causes work starvations for downstream trade contractors and therefore deviations from project plans. 
According to the results presented in Table 3, availability and throughput rate are identical for experiments. Therefore these production parameters cannot reflect the effect of different timeframes for rework call-backs. Variability indicator (VI) is a more useful parameter that evaluates the smoothness of job movements between trade contractors. Readers can refer to Hopp and Spearman (2008) for more information about variability computations. Eqs. (7) and (8) calculate VI when rework occurs during or between construction processes:

$$
\begin{aligned}
& (\mathrm{VI})^{2}=0.1+A(1-A) \frac{\boldsymbol{D O R}}{\boldsymbol{t}} \text { (during processes) } \\
& (\mathrm{VI})^{2}=\frac{\boldsymbol{R I}\left(\frac{\boldsymbol{R} \boldsymbol{I}}{\boldsymbol{t}}-\mathbf{0 . 5}\right)}{\boldsymbol{t}(\boldsymbol{R I}+\boldsymbol{D O O})} \text { (between processes) }
\end{aligned}
$$

In Eq. (8), RI= rework interval.

Table 4 shows the variability indicators (VI) for different timeframes of rework call-backs.

Table 4. Quantitative comparison of variability indicator (VI) for different call-back timeframes

\begin{tabular}{l|llll}
\hline Parameters & VF-VS & F-S & I-L & VI-VL \\
\hline On time/early call-backs & 0.25 & 0.43 & 0.56 & 0.66 \\
Late call-back & 0.34 & 0.64 & 0.75 & 0.85 \\
\hline
\end{tabular}

The results in Table 4 show, VI is smaller when construction supervisors at the site made early or on time call-backs to rectify the faults. Late call-backs, however, dramatically increased VI. This finding places extra emphasis on importance of being proactive for building supervisors in terms of finding incidents of fault and call the responsible trade contractor back before their resources have been released and reengaged to do another job. Also the probability of conflict computed by Eq. (6) shows that construction systems ruled by such management strategy are less likely to face future rework before depletion of the previous queue.

This is worth mentioning that there is a striking difference between production construction and manufacturing in this case because in manufacturing rework is traditionally regarded as a process, which always happens between other processes and does not interrupt them (Hopp and Spearman 2008). Within the construction context, rework often becomes priority work especially when a 
mandatory inspection should be passed at major stages of a given project (Sawhney, Walsh et al. 2009).

\section{Simulation modeling}

In the second phase of the research the complete model of production homebuilding, including about 50 trades, was simulated over 1000 working days. In order to approximate the number of required simulation runs for our 12 experiments, the first experiment was simulated for $\mathrm{N}_{0}=20$ runs. In this situation, the sample average house completion time was $\bar{X}=275.78$ days and the $95 \%$ confidence interval for true population mean was $275.78 \pm 7$ days. This represents $2.5 \%$ error in the point estimate of average completion time.

As the half width of the confidence interval for 20 runs was disappointingly high, we decided to reduce it from $\mathrm{h}_{0}=7$ days to $\mathrm{h}=3$ days in order to decrease the error in the point estimate of average house completion time to less than 1\%. Kelton, Sadowski et al. (2010) suggested that the optimum number of simulation runs based on a pre-specified half width (h) can be approximated by Eq. (9):

$\mathrm{N}=\mathrm{N}_{0} \frac{\boldsymbol{h}_{\mathbf{0}}{ }^{2}}{\boldsymbol{h}^{\mathbf{2}}}$

In Eq. (9), $\mathrm{N}_{0}=$ number of initial simulation runs; $\mathrm{h}_{0}=$ half width confidence resultant from the initial number of runs; and $h=$ desired half width. In our simulation experiment, $\mathrm{N} \approx 20 \times 7^{2} / 3^{2}=100$. Running the simulation experiment for 100 times produced a $95 \%$ confidence interval of $274.32 \pm$ 2.53 days. In other words, there is $95 \%$ certainty that the true population mean falls between 271.79 and 276.85 .

In order to control statistical sufficiency, experiments 7 and 8 were simulated for 200 and 500 runs. The comparison of results did not reveal any significant difference between errors in the point estimation of average house completion time under 100, 200 and 500 runs. Therefore other experiments were simulated for 100 runs. 
A simplified representation of activity cycle diagram for the house building operation is shown in Fig.

7. Only major processes and resources have been illustrated in this figure.

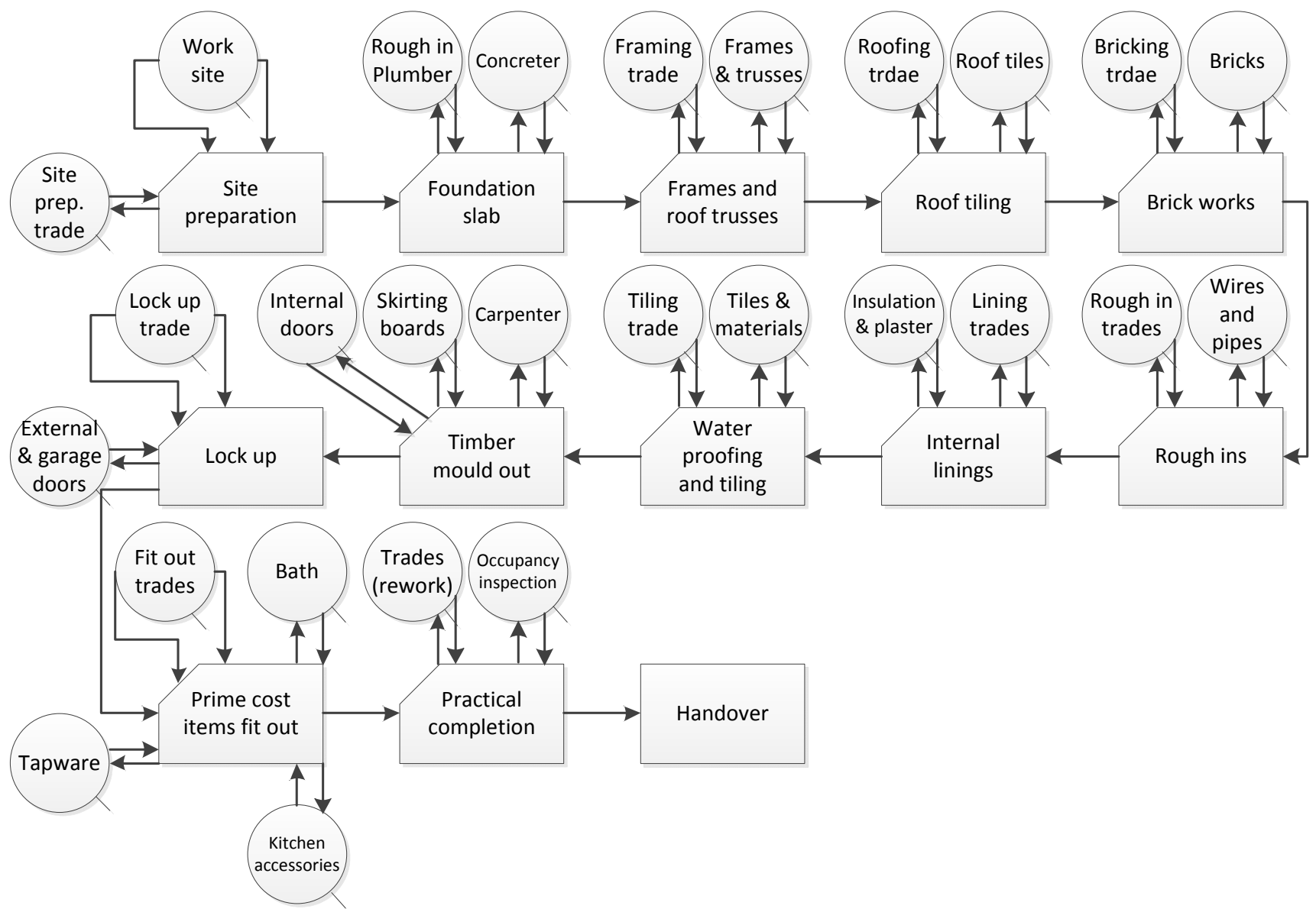

Fig. 7. Simplified representation of activity cycle diagram for house building operation

Obviously such a model is too complex to be solved analytically. Although smaller variability indicators for early call-backs showed a better level of productivity in our mathematical modeling, tangible performance measures in volume homebuilding cannot be computed analytically and therefore simulation modeling is required (Henderson, Vaughan et al. 2003). The objective of simulation modeling in this study is to validate the results of mathematical modeling. Also generalizability of the findings for individual processes to the whole system is investigated.

Flow of work between trade contractors (hand-off) is an important attribute in mass homebuilding. Workflow analysis reveals output rate of each process that is equal to job arrival rate for next immediate processes. To compute the number of houses under construction (work-in-process inventory), the same technique as that used by Palaniappan, Sawhney et al. (2007) was utilized. Care 
was taken to model the effects of different timeframes for rework call-backs on arrival rates of downstream trade contractors. Fig. 8 shows a snapshot of SIMAN coding windlow for this purpose. The readers can refer to Kelton, Sadowski et al. (2010) and Arashpour, Wakefield et al. (2013) for additional details.

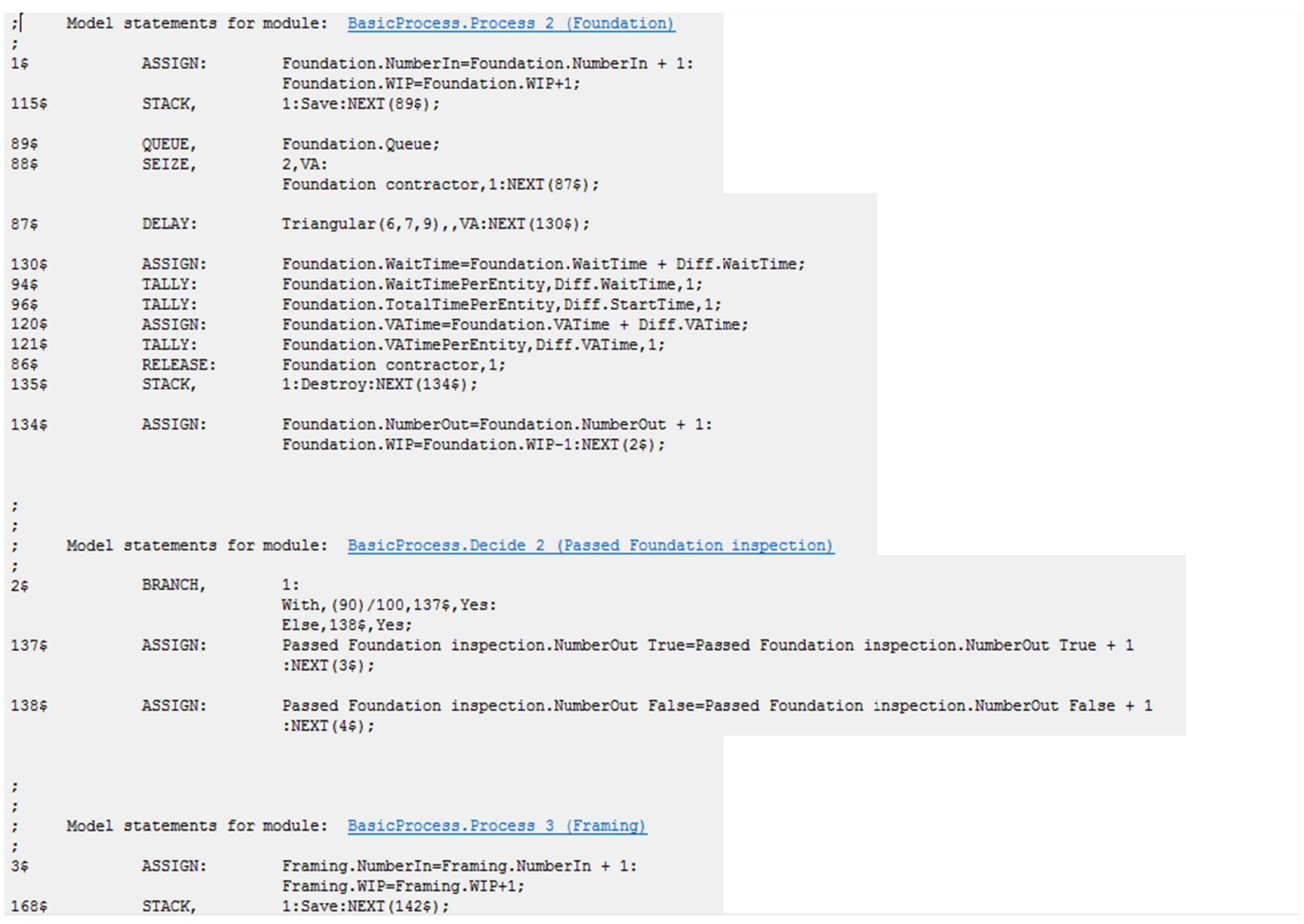

Fig. 8. SIMAN code window for workflow analysis

Using SIMAN coding, tangible performance measures of the homebuilding project were computed. These include number of house completions over the investigation period, the average number of houses under construction (work-in-process inventory) at all times, and the duration between start and end of processing a home (cycle time $=\mathrm{CT}$ ). A summary of simulation results over 1000 working days has been presented in table 5. It should be noted that detached suburban houses in Australia are not usually constructed in tracts and completion times are generally longer than those of other homebuilding markets, particularly the U.S. market. In this way, homebuyers sometimes have to spend several months in the preoccupancy period, especially during boom periods when demand overtakes supply. 
Table 5. Relationship between performance measures and rework variables

\begin{tabular}{ccccccc}
\hline Experiment & $\begin{array}{c}\text { Rework } \\
\text { call-backs }\end{array}$ & $\begin{array}{c}\text { Rework } \\
\text { frequency } \\
\text { (Interval) }\end{array}$ & $\begin{array}{c}\text { Duration } \\
\text { of rework }\end{array}$ & $\begin{array}{c}\text { Completed } \\
\text { homes (No.) }\end{array}$ & $\begin{array}{c}\text { Homes under } \\
\text { construction } \\
\text { (WIP inventory) }\end{array}$ & $\begin{array}{c}\text { Average CT } \\
\text { (days/home) }\end{array}$ \\
\hline $\mathbf{1}$ & On-time & Very frequent & Very short & 91 & 34 & 274 \\
\hline $\mathbf{2}$ & On-time & frequent & Short & 85 & 37 & 295 \\
\hline $\mathbf{3}$ & On-time & Infrequent & Long & 83 & 39 & 312 \\
$\mathbf{4}$ & On-time & Very infrequent & Very long & 79 & 41 & 332 \\
$\mathbf{5}$ & Late & Very frequent & Very short & 82 & 39 & 317 \\
$\mathbf{6}$ & Late & frequent & Short & 76 & 42 & 340 \\
\hline $\mathbf{7}$ & Late & Infrequent & Long & 74 & 43 & 357 \\
\hline $\mathbf{8}$ & Late & Very infrequent & Very long & 72 & 44 & 364 \\
\hline $\mathbf{9}$ & Early & Very frequent & Very short & 98 & 31 & 243 \\
\hline $\mathbf{1 0}$ & Early & frequent & Short & 95 & 33 & 266 \\
\hline $\mathbf{1 1}$ & Early & Infrequent & Long & 90 & 35 & 283 \\
\hline $\mathbf{1 2}$ & Early & Very infrequent & Very long & 88 & 37 & 297 \\
\hline
\end{tabular}

The box and whisker chart in Fig. 9 illustrates the completion times in different experiments.

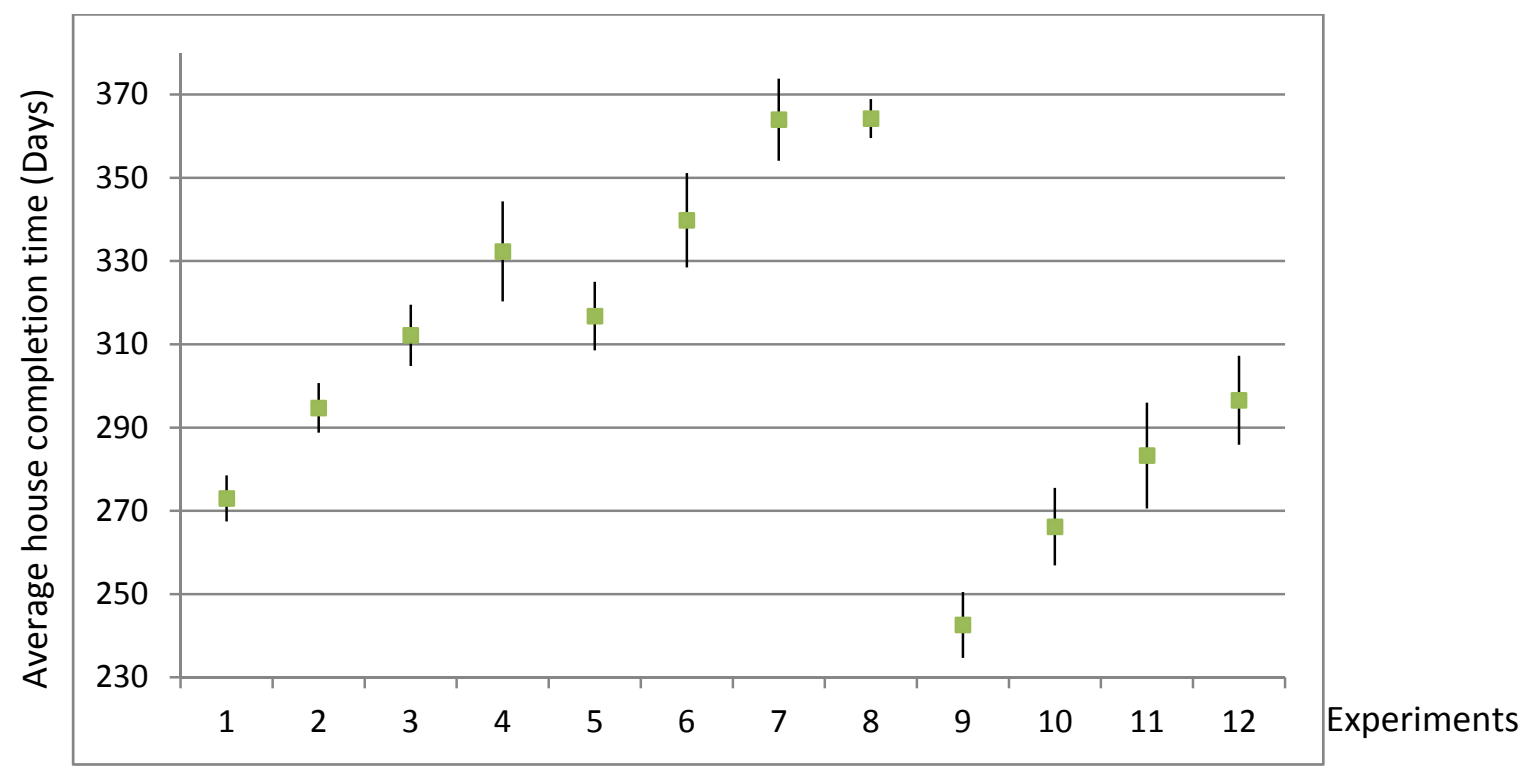

Fig. 9. Average completion times in 12 experiments

\section{Relationship between rework call-backs and production parameters}

Simulation results clearly show that call-back timeframe has a considerable impact on tangible performance measures in homebuilding sector. That is, early call-backs for rework can significantly increase the number of house completions and decrease average completion times. This is consistent with results of mathematical modeling that show a lower variability indicator (VI) for those projects with an early call-back strategy in place, which promises a smoother movement of jobs between trade contractors and therefore higher levels of productivity. In other words, local variation in trade 
processes, which was analyzed in mathematical modeling, can affect the performance of the whole network. According to table 5, the shortest completion time for a house is when early call-backs for rework were made when trade contractors have not released their resources yet (experiment 9). Furthermore, Lower levels of WIP inventory in projects with early call-back for rework resulted in lighter loading on available resources and shorter home completion times. The highest number of 98 house completions was achieved in such situation.

A factorial analysis of variance (ANOVA) was conducted to quantitatively assess the effect of rework variables on house completion times. For ANOVA analysis, F-Statistics is computed using Eq. (10):

$\mathrm{F}=\frac{\text { Sum of squares between groups } / \mathrm{DF} 1}{\text { Sum of squares within groups } / D F 2}$

In Eq. (10), $\mathrm{DF}_{1}=$ Between group degree of freedom; and $\mathrm{DF}_{2}=$ Within group degree of freedom

Results of factorial ANOVA in Table 5 clearly show that both independent variables of call-back timeframe $(\alpha)$ and frequency/duration of rework $(\beta)$ have significant impacts on the dependent variable of house completion times (P-value $<0.05)$. The comparison of sum of square values for $\alpha$ and $\beta$ suggests that the impact of call-back timeframe on house completion time is more than rework frequency/duration. Furthermore, analyzing 1200 completion times (100 runs for each of 12 experiments) showed that there is an interaction between the two independent variables of call-back timeframes and frequency/length of rework. Table 6 shows that there is significant difference among the means of average house completion times when two independent variables $(\alpha \times \beta)$ are interacting.

Table 6. Test of between-subject effects for the dependent variable (average house completion time)

\begin{tabular}{cccccc}
\hline Source & $\begin{array}{c}\text { Type III } \\
\text { Sum of } \\
\text { Squares }\end{array}$ & $\begin{array}{c}\text { Degree } \\
\text { of } \\
\text { freedom }\end{array}$ & Mean Square & F Statistics & P-value \\
\hline Corrected model & 293881.065 & 11 & 26716.460 & 165.791 & 0.000 \\
Intercept & 22586198.94 & 1 & 22586198.938 & 140160.668 & 0.000 \\
Call-back Timeframe $(\alpha)$ & 202085.230 & 2 & 101042.615 & 627.029 & 0.000 \\
\hline Rework Frequency \& Duration $(\beta)$ & 88705.391 & 3 & 29568.464 & 183.490 & 0.001 \\
\hline$\alpha \times \beta$ & 3090.444 & 6 & 515.074 & 3.196 & 0.005 \\
\hline Error & 36741.073 & 1188 & 161.146 & & \\
\hline Total & 22916821.08 & 1200 & & & \\
\hline Corrected total & 330622.138 & 1199 & & & \\
\hline
\end{tabular}


Having identical levels of availability for trade contractors, those construction processes that experienced more frequent but shorter rework achieved shorter completion times. This is consistent with results of mathematical modeling where job queue length was shorter in such situations and therefore provides a measure of validation. Queue depletion time (QDT) was also shorter than those projects with infrequent but longer rework.

Knowing the significant impact of both rework variables and their interaction on average house completion times, a multiple comparison of variables was then conducted. Scheffe's HSD (honestly significant difference) test was performed to compare all possible pairs of means to identify the groups with significant difference. Table 7 presents the multiple comparisons of average house completion times in presence of on time, late and early timeframes for rework call-backs.

Table 7. Post-hoc test for multiple comparisons of rework timeframes

\begin{tabular}{ccccc}
\hline $\begin{array}{c}\text { (I) Call- back } \\
\text { timeframe }\end{array}$ & $\begin{array}{c}\text { (J) Call-back } \\
\text { timeframe }\end{array}$ & $\begin{array}{c}\text { Mean Difference (I- } \\
\text { J) }\end{array}$ & Std. Error & P-value \\
\hline \multirow{2}{*}{ On time } & Late & -37.4725 & 1.00714 & 0.000 \\
& Early & 33.5701 & 1.00714 & 0.000 \\
Late & On time & 37.4725 & 1.00714 & 0.000 \\
& Early & 71.0426 & 1.00714 & 0.000 \\
\multirow{2}{*}{ Early } & On time & -33.5701 & 1.00714 & 0.000 \\
& Late & -71.0426 & 1.00714 & 0.000 \\
\hline
\end{tabular}

As can be seen, the largest mean difference value $(\mathrm{I}-\mathrm{J})$ belongs to the comparison of average house completion times for late and early call-backs for rework (71.04 days). The relative P-values confirm the significant difference in house completion times under different scenarios. The comparison of mean house completion times, when there are on time and late rework callbacks, results in 37.47 days of difference. Understandably, $\mathrm{I}-\mathrm{J}=71.04-37.47=33.57$ days when the mean house completion times are compared for on time early call-backs for rework.

Overall, average house completion times are significantly different when comparing possible pairs of call-back timeframes. In other words, our analysis in table 6 shows that independent variable of callback timeframe has a significant effect on dependent variable of average house completion time. 
Furthermore, results in table 7 confirm that different levels of the independent variable can also significantly affect the dependent variable, highlighting the criticality of call-back timeframes.

Finally, a cross-experiment comparison of resource utilizations highlights the significant effect of the rework variables on tangible performance measures (see Fig. 10). For instance, frequent but short rework in experiment 9 along with early call-backs for rework have resulted in the best resource utilization level comparing with other experiments. Furthermore, the significant difference in house completion times in experiments 8 and 9 (121 days) can be justified by trade contractor utilization levels. Fig. 10 illustrates utilization levels of 50 trade contractors in the cross comparison of experiments 8 (worst case) and experiment 9 (best case).

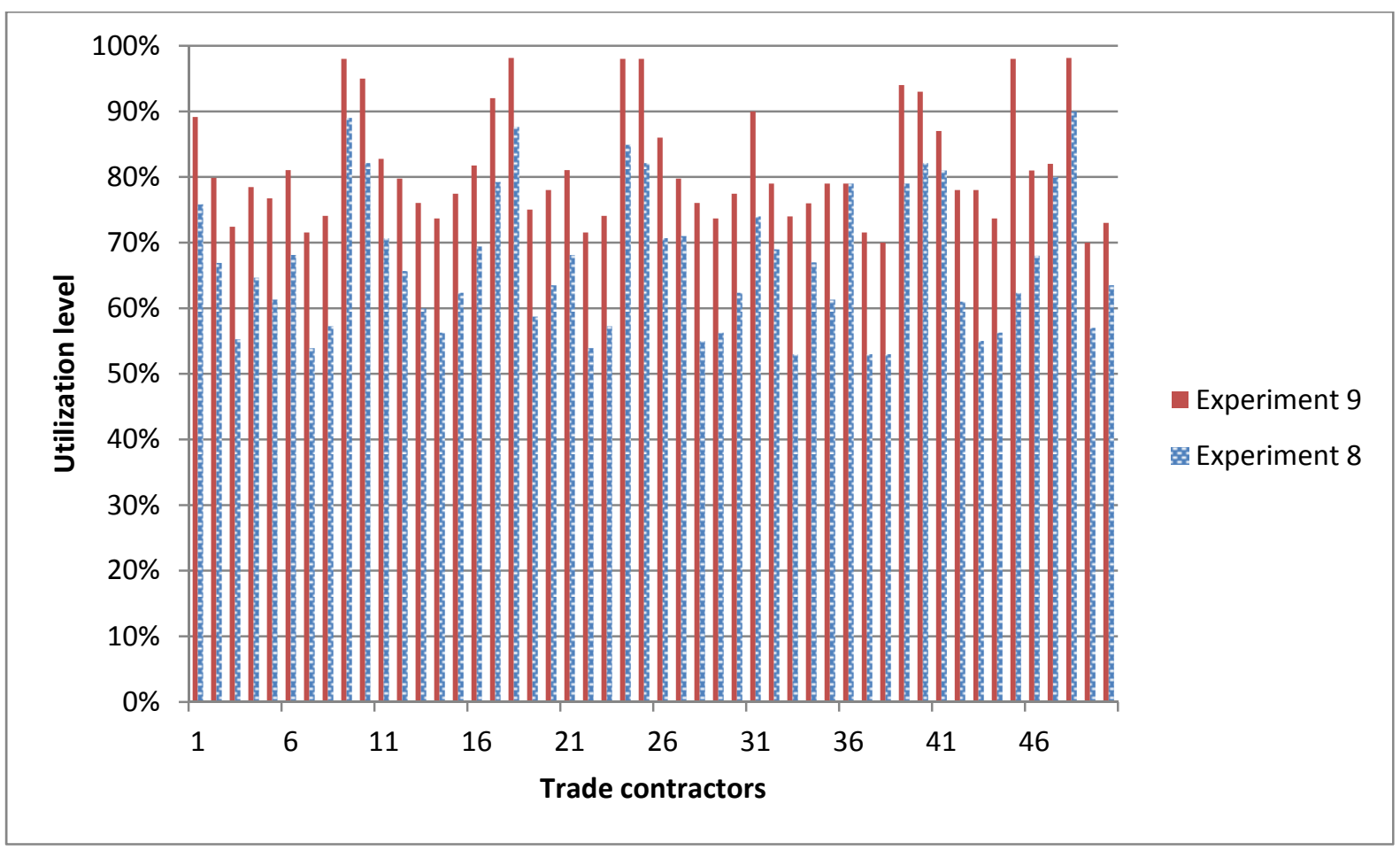

Fig. 10. Cross-experimental comparison of resource utilization levels (experiments 8 and 9)

As can be seen the average utilization level stood at $81 \%$ in experiment 9 . Also, the maximum trade contractor utilization level reached a peak of $98 \%$. In fact, trade contractors were busy most of the time, indicating the more efficient use of available resources. In contrast, infrequent but long rework along with late call-backs for rework can result in idleness of resources. In terms of trade contractor utilization, experiment 8 demonstrates a considerably poorer performance than other experiments. 
According to Fig. 10, the average utilization level of trade contractors was $67 \%$ and the minimum utilization level hit a low of 53\%, which means some trade contractors were idle almost half the time.

Overall, late call-backs for rework along with infrequent but lengthy rework significantly downgrade the tangible performance measures of mass homebuilders. This implies that fault finding at source is the best practice to decrease time overruns caused by rework (Arashpour, Wakefield et al. 2013). Rewarding trade contractors who rectify their own faults before being called back by building supervisors or other trade contractors could prevent later lengthy rework. This is similar to the paradigm of Total Quality Management (TQM) in manufacturing that aims at a continuous quality improvement for processes (Hradesky 1995).

\section{Conclusions}

Prior work has documented the effects of rework and resultant interruptions on construction projects (Love 2002, Arashpour, Wakefield et al. 2013). However, these studies are limited in application given their use of abstract models to illustrate the effects of rework and consideration of only longer than average duration of processes requiring rework. In order to investigate the interruptions more precisely, this study modeled rework in detail, considering its frequency/length and timeframe for the call-back process. Several simulation experiments were designed using data from two homebuilders and collected by numerous work site observations.

Quantitative analysis of mathematical modeling and simulation results showed that production parameters are directly related to rework variables. Infrequent but long rework is found to have more negative effects on house completion times compared with frequent but short rework, even if the overall levels of system capacity and resource availability are identical. In comparing on time, late, and early call-backs for the responsible trade contractor, the most dramatic adverse effect on production parameters is observed when the contractor is called back late. In this event, the trade contractor has moved their crews to a new work site. A call-back for rework interferes with their processes and lengthens the house completion times. The findings obtained from mathematical and 
simulation modeling are consistent and extend those of Dalton, Wakefield et al. (2011) and Hegazy, Said et al. (2011), confirming that rework should be incorporated into construction schedule analysis.

Complications caused by rework result in lengthened house completion times. Our findings clearly show that frequency and duration of rework along with timeframe for call-backs are a significant combination of variables that affect house completion times and the number of completions and therefore should be considered in construction scheduling. The contribution of this work to the body of knowledge is to develop an in-depth insight into effects of rework on construction production. This research is generalizable to other sectors of the construction industry in order to investigate effects of rework on tangible performance measures. In order to determine the strength of this analytical approach, future research should incorporate more stochastic variables into the model to better reflect the reality in construction sites and further our understanding about dynamics and effects of rework in the construction production.

\section{Acknowledgement}

The project is partly funded by a scholarship award from Royal Melbourne Institute of Technology, Australia. The authors would like to express their appreciation to Ms. Jennifer Anderson in RMIT Study and Learning Centre.

\section{Appendix}

The simulated model of production homebuilding is illustrated in Fig. 11. 


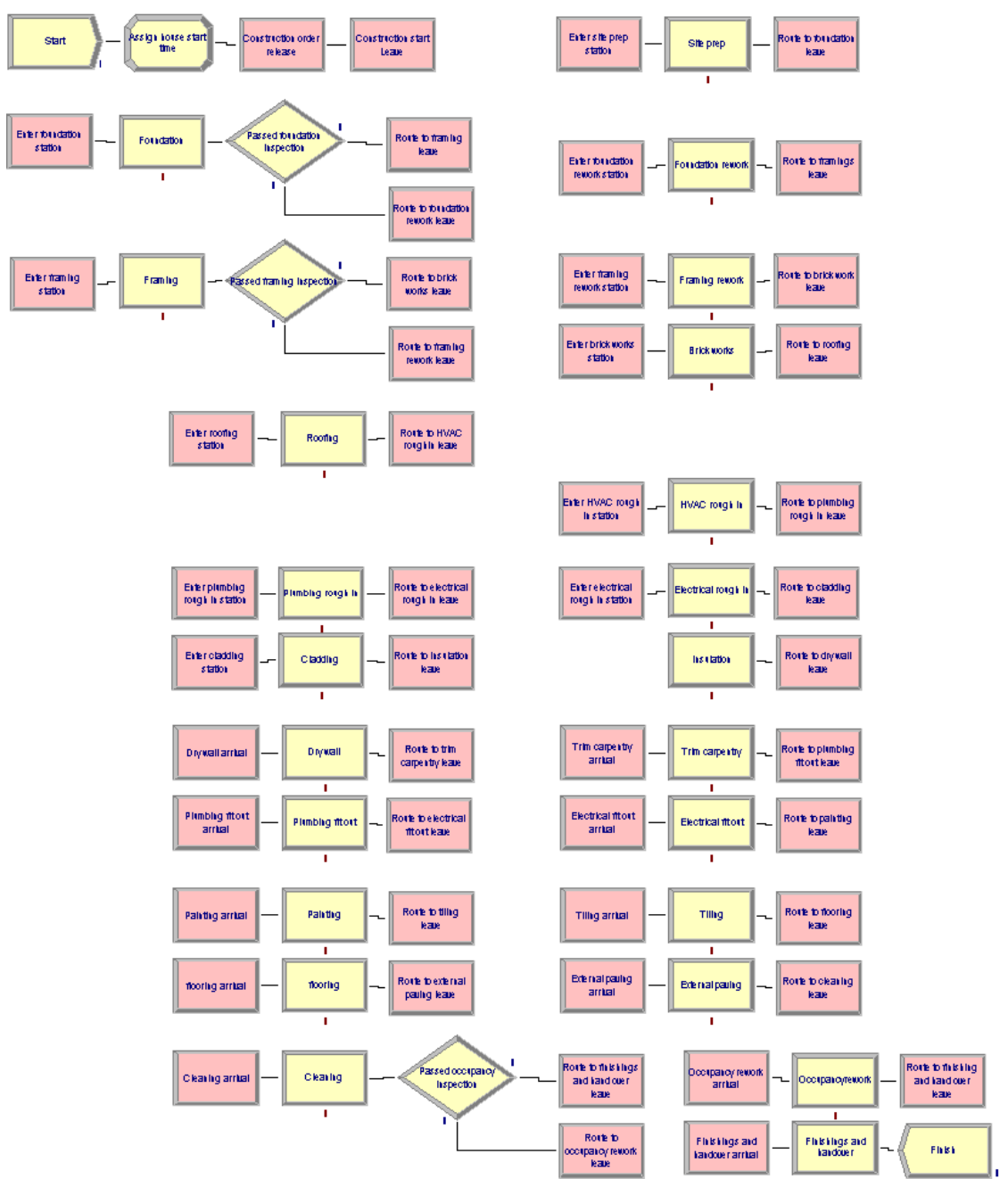

Fig. 11 House building simulation model

\section{References}

AbouRizk, H. and S. Hague (2009). An overview of the COSYE environment for construction simulation. Proceedings of the 2009 Winter Simulation Conference (WSC).

AbouRizk, S., D. Halpin, Y. Mohamed and U. Hermann (2011). "Research in modeling and simulation for improving construction engineering operations." Journal of Construction Engineering and Management 137(10): 843.

AbouRizk, S. M. and D. Hajjar (1998). "A framework for applying simulation in construction." Canadian journal of civil engineering 25(3): 604-617.

Akhavian, R. and A. H. Behzadan (2011). Dynamic data driven simulation of ongoing construction processes. Annual Conference of the Canadian Society for Civil Engineering 2011, CSCE 2011, Ottawa, ON.

Arashpour, M. and M. Arashpour (2010). "Gaining the Best Value from HR in Construction Companies." Proceedings of the 6th European Conference on Management Leadership and Governance: 23-33.

Arashpour, M., M. Shabanikia and M. Arashpour (2012). "Valuing the contribution of knowledgeoriented workers to projects: a merit based approach in the construction industry." Australasian Journal of Construction Economics and Building 12(4): 1- 12. 
Arashpour, M., R. Wakefield and N. Blismas (2013). Improving construction productivity: implications of even flow production principles. CIB World Building Congress 2013: Construction and Society, Queensland University of Technology.

Arashpour, M., R. Wakefield and N. Blismas (2013). Role of simulation in construction processesharmony in capturing resources. Research, Development and Practice in Structural Engineering and Construction (ASEA-SEC), Research Publishing Services (RPS).

Arashpour, M., R. Wakefield, N. Blismas and E. W. M. Lee (2013). "A new approach for modelling variability in residential construction projects." Australasian Journal of Construction Economics and Building 13(2): 83-92.

Ballard, G. and L. Koskela (2009). Design should be managed as a physical process, too, Palo Alto, CA.

Bashford, H. H., K. D. Walsh and A. Sawhney (2003). Relationships between System Loading and Cycle Time in a Residential Construction Production System. Construction Research Congress, Honolulu, HI.

Behzadan, A. H. and V. R. Kamat (2011). "Integrated information modeling and visual simulation of engineering operations using dynamic augmented reality scene graphs." Electronic Journal of Information Technology in Construction 16: 259-278.

Boukamp, F. and B. Akinci (2007). "Automated processing of construction specifications to support inspection and quality control." Automation in Construction 17(1): 90-106.

Brodetskaia, I., R. Sacks and A. Shapira (2013). "Stabilizing Production Flow of Interior and Finishing Works with Reentrant Flow in Building Construction." Journal of Construction Engineering and Management 139(6): 665-674.

Chang, D. Y.-M. (1986). RESQUE: A RESOURCE BASED SIMULATION SYSTEM FOR CONSTRUCTION PROCESS PLANNING (NETWORK, ALLOCATION). Ph.D. PhD, PhD dissertation, University of Michigan.

Cheng, T.-m. and C.-w. Feng (2003). "An effective simulation mechanism for construction operations." Automation in Construction 12(3): 227-244.

Choi, K., Y. Kwak, J. Pyeon and K. Son (2011). "Schedule Effectiveness of Alternative Contracting Strategies for Transportation Infrastructure Improvement Projects." Journal of Construction Engineering and Management 138(3): 323-330.

Clemmens, J. P. and J. H. Willenbrock (1978). "The SCRAPESIM computer simulation." Journal of the Construction Division 104(4): 419-435.

Dalton, T., R. Wakefield and R. Horne (2011). "Australian suburban house building: industry organisation, practices and constraints." Australian Housing and Urban Research Institute Positioning Paper Series: 1-56.

Damrianant, J. and R. R. Wakefield (2000). "An alternative approach for modeling of interference in discrete-event systems." Civil Engineering and Environmental Systems 17(3): 213-235.

Fayek, A. R., M. Dissanayake and O. Campero (2004). "Developing a standard methodology for measuring and classifying construction field rework." Canadian Journal of Civil Engineering 31(6): 1077-1089.

Feng, P. P.-Y. (2009). Causes and effects of rework on the delivery of healthcare facilities in California. Ph.D. 3383064, PhD dissertation, University of California, Berkeley.

Garza, J., D. Hancher and L. Decker (2000). "Analysis of Safety Indicators in Construction." Journal of Construction Engineering and Management 124(4): 312-314.

González, V., L. F. Alarcón and K. Molenaar (2009). "Multiobjective design of Work-In-Process buffer for scheduling repetitive building projects." Automation in Construction 18(2): 95-108.

Hajjar, D. (1999). A unified modeling methodology for simulation-based planning of construction projects. Ph.D. NQ46845, PhD dissertation, University of Alberta (Canada).

Hajjar, D. and S. AbouRizk (1997). AP2-Earth: a simulation based system for the estimating and planning of earth moving operations. Proceedings of the 29th conference on Winter simulation, IEEE Computer Society.

Halpin, D. W. (1973). AN INVESTIGATION OF THE USE OF SIMULATION NETWORKS FOR MODELING CONSTRUCTION OPERATIONS. Ph.D. 7405585, PhD dissertation, University of Illinois at Urbana-Champaign. 
Halpin, D. W. and R. W. Woodhead (1976). Design of construction and process operations, John Wiley \& Sons, Inc.

Hegazy, T., M. Said and M. Kassab (2011). "Incorporating rework into construction schedule analysis." Automation in Construction 20(8): 1051-1059.

Henderson, D., D. E. Vaughan, S. H. Jacobson, R. R. Wakefield and E. C. Sewell (2003). "Solving the shortest route cut and fill problem using simulated annealing." European Journal of Operational Research 145(1): 72-84.

Hopp, W. J., S. M. R. Iravani and Z. Liu (2011). "Mitigating the Impact of Disruptions in Supply Chains." Supply Chain Disruptions: Theory and Practice of Managing Risk: 21.

Hopp, W. J. and M. L. Spearman (2004). "To pull or not to pull- what is the question?" Manufacturing and Service Operations Management 6(2): 133-148.

Hopp, W. J. and M. L. Spearman (2008). Factory physics, McGraw-Hill Irwin Irwin.

Hradesky, J. (1995). Total quality management handbook, McGraw-Hill.

Huang, R.-Y. and D. W. Halpin (1995). "Graphical-based method for transient evaluation of construction operations." Journal of construction engineering and management 121(2): 222-229.

Hwang, S., M. Park, H. Lee, S. Lee and H. Kim (2012). "Dynamic Feasibility Analysis of the Housing Supply Strategies in a Recession: Korean Housing Market." Journal of Construction Engineering and Management 139(2): 148-160.

Jen, H. (2005). Web-based construction process simulation framework. Ph.D. 3185780, PhD dissertation, Purdue University.

Kamat, V. R. (2003). VITASCOPE: Extensible and scalable 3D visualization of simulated construction operations, $\mathrm{PhD}$ dissertation, Virginia Polytechnic Institute and State University.

Kamat, V. R. and J. C. Martinez (2008). "Generic representation of 3D motion paths in dynamic animations of simulated construction processes." Automation in Construction 17(2): 188-200.

Kavanagh, D. P. (1985). "SIREN: A repetitive construction simulation model." Journal of construction engineering and management 111(3): 308-323.

Kelton, W. D., R. P. Sadowski and N. Swets (2010). Simulation with ARENA, McGraw-Hill Boston, MA.

Koskela, L. (2000). An exploration towards a production theory and its application to construction, $\mathrm{PhD}$ dissertation, Helsinki University of Technology, VTT Technical Research Centre of Finland.

Little, J. D. C. (1961). "A proof for the queuing formula: $L=\lambda$ W." Operations Research 9(3): 383387.

Liu, L. (1991). COOPS: Construction object-oriented simulation system, PhD dissertation, University of Michigan, Ann Arbor, Mich.

Lluch, J. and D. W. Halpin (1982). "Construction operation and microcomputers." Journal of the Construction Division 108(1): 129-145.

Love, P. (2002). "Influence of Project Type and Procurement Method on Rework Costs in Building Construction Projects." Journal of construction engineering and management 128(1): 18-29.

Love, P., G. Holt, L. Shen, H. Li and Z. Irani (2002). "Using systems dynamics to better understand change and rework in construction project management systems." International Journal of Project Management 20(6): 425-436.

Love, P. E. D., D. J. Edwards, J. Smith and D. H. T. Walker (2009). "Divergence or congruence? A path model of rework for building and civil engineering projects." Journal of performance of constructed facilities 23(6): 480-488.

Love, P. E. D., D. J. Edwards, H. Watson and P. Davis (2010). "Rework in civil infrastructure projects: determination of cost predictors." Journal of construction engineering and management 136(3): 275-282.

Lu, M., M. Anson, S. Tang and Y. Ying (2003). "HKCONSIM: A practical simulation solution to planning concrete plant operations in Hong Kong." Journal of construction engineering and management 129(5): 547-554.

Lu, X. and Z. Ni (2008). Modeling Study of JIT System Based on Colored Petri Nets. Logistics: 1995-2001. 
Martinez, J. C. (2010). "Methodology for Conducting Discrete-Event Simulation Studies in Construction Engineering and Management." Journal of Construction Engineering and Management-Asce 136(1): 3-16.

Martínez, J. C. (1996). STROBOSCOPE: State and resource based simulation of construction processes. PhD, PhD dissertation, University of Michigan, Ann Arbor, Mich.

McCahill, D. F. and L. E. Bernold (1993). "Resource-oriented modeling and simulation in construction." Journal of Construction Engineering and Management 119(3): 590-606.

Mubarak, S. (2010). Construction project scheduling and control, Wiley.

Naresh, A. L. and C. T. Jahren (1995). "Process simulation for guide wall construction using mobile cofferdams." Transportation Research Record(1511): 1-9.

O'Brien, W. J., T. K. Wang, M. Siddiqui, J. Hammer and R. Wakefield (2006). Process Connectors: Linking Distributed Processes In The Construction Supply Chain. Joint International Conference on Computing and Decision Making in Civil and Building Engineering, Montréal, Canada.

Odeh, A. M. (1992). CIPROS: Knowledge-based construction integrated project and process planning simulation system. PhD, PhD dissertation, University of Michigan, Ann Arbor, Mich.

Palaniappan, S., A. Sawhney, H. H. Bashford and K. D. Walsh (2007). Special purpose simulation template for workflow analysis in construction, Washington, DC.

Paulson Jr, B. C., W. T. Chan and C. C. Koo (1987). "Construction operations simulation by microcomputer." Journal of construction engineering and management 113(2): 302-314.

Petri, C. A. (1966). Communication with automata. PhD, PhD dissertation, University of Bonn.

Rajendran, S., J. Gambatese and M. Behm (2009). "Impact of Green Building Design and Construction on Worker Safety and Health." Journal of construction engineering and management 135(10): 1058-1066.

Salazar-Kish, J. M. (2001). Modeling concurrency tradeoffs and their effects on project duration and rework. Ph.D. 3002040, PhD dissertation, Stanford University.

Salem, O., J. Solomon, A. Genaidy and I. Minkarah (2006). "Lean Construction: From Theory to Implementation." Journal of management in engineering 22(4): 168-175.

Sawhney, A., O. Abudayyeh and T. Chaitavatputtiporn (1999). "Modeling and analysis of concrete production plant using petri nets." Journal of Computing in Civil Engineering 13(3): 178-186.

Sawhney, A., H. Bashford, S. Palaniappan, K. Walsh and J. Thompson (2005). A discrete event simulation model to analyze the residential construction inspection process. ASCE International Conference on Computing in Civil Engineering

Cancun.

Sawhney, A., K. D. Walsh, H. H. Bashford and S. Palaniappan (2009). "Impact of inspected buffers on production parameters of construction processes." Journal of construction engineering and management 135(4): 319-329.

Thompson, P. and J. G. Perry (1992). Engineering construction risks: A guide to project risk analysis and assessment implications for project clients and project managers, Thomas Telford.

Tommelein, I., D. Riley and G. Howell (1999). "Parade Game: Impact of Work Flow Variability on Trade Performance." Journal of construction engineering and management 125(5): 304-310.

Touran, A. (2010). "Probabilistic approach for budgeting in portfolio of projects." Journal of Construction Engineering and Management 136(3): 361-366.

Tuholski, S. J. (2008). Transformation, flow, and value constellations in AEC projects, ProQuest.

Wakefield, R. R. and G. A. Sears (1997). "Petri nets for simulation and modeling of construction systems." Journal of construction engineering and management 123(2): 105-112.

$\mathrm{Yu}, \mathrm{H}$. (2011). An integrated approach toward lean for production homebuilders, PhD dissertation, University of Alberta. 